\title{
Addendum
}

\section{One-Pot Organocatalytic Direct Asymmetric Synthesis of $\gamma$-AminoAlcohol Derivatives}

Armando Córdova Synlett 2003, 1651.

The Scripps Research Institute, 10550 North Torrey Pines Road, La Jolla, CA 92037, USA

Addendum by the Editors of SYNLETT and the Publisher concerning the above-mentioned paper, which was Received: May 21 $1^{\text {st }}, 2003$

Published online: August $25^{\text {th }}, 2003$

Published in print: September $2^{\text {nd }}, 2003$

A recent publication in Chemical and Engineering News (March 12 ${ }^{\text {th }}, 2007$, Volume 85, Number 12, pp. 35-38: "Giving Proper Credit, Ethics violations by a chemist in Sweden highlight science's unpreparedness to deal with misconduct") has reported about the circumstances of the above-mentioned publication in Synlett.

The author of the Synlett publication, Armando Córdova, is now affiliated with the Faculty of Science at the University of Stockholm, Sweden. An investigation of Professor Córdova was conducted by chemistry Professors Olov Sterner and Torbjörn Frejd of Lund University, Sweden.

The Synlett publication was based on a manuscript sent in December 2002 to, but rejected by, The Journal of the American Chemical Society and in its earlier form it had the three authors Armando Córdova, James Turner, and Carlos Barbas III. The almost identical manuscript was sent subsequently to Tetrahedron Letters on February $17^{\text {th }}, 2003$, with only Professor Córdova as the author. Although it was accepted for publication, it was retracted after intervention by Professor Carlos Barbas III (The Scripps Research Institute), who was Professor Córdova's supervisor when he was affiliated with the Scripps Research Institute.
Professor Córdova then submitted the manuscript to Synlett on May $21^{\text {st }}, 2003$. The paper was accepted and published on August 25 ${ }^{\text {th }}$, 2003. Professor Carlos Barbas III has informed the Editors of Synlett and the Publisher that this publication is not an authorized contribution from the Scripps Research Institute.

The report of Professors Olov Sterner and Torbjörn Frejd concludes:

"It is clear that Professor Córdova behaved unethically concerning the Synlett paper."

It is much to the regret of the Editors and the Publisher of Synlett that the paper has been published in Synlett. 